\title{
Cd(II) sensing in water using novel aromatic iminodiacetate based fluorescent chemosensors
}

\section{Thorfinnur Gunnlaugsson, ${ }^{*}{ }^{\dagger}$ Clive Lee ${ }^{\ddagger}$ and Raman Parkesh $^{\dagger}$}

Department of Chemistry, Trinity College Dublin, Dublin 2, Ireland and Department of Anatomy, Royal College of Surgeons in Ireland, St. Stephen's Green, Dublin 2, Ireland.

\section{Supporting Information}

Synthesis

\section{Synthesis of 6}

9-Chloromethylanthracene $(1.5 \mathrm{~g}, 6.64 \mathrm{mmol})$, phenyliminodi-acetic acid diethyl ester 2 (1.76 g.6.64 mmol) and $\mathrm{AlCl}_{3}(.91 \mathrm{~g}, 6.64 \mathrm{mmol})$ were dissolved in dry $\mathrm{CHCl}_{3}(50 \mathrm{~mL})$ at $0^{0} \mathrm{C}$. The solution was refluxed under stirring overnight. After the reaction was complete, (monitoring by TLC) the solution was cooled and washed with three $100 \mathrm{ml}$ portions of water. The organic portion was dried over $\mathrm{MgSO}_{4}$. After evaporation of the solvent, crude product was subjected to column chromatography and yielded pure $6(1.81 \mathrm{~g}, 60 \%)$ as light yellow solid. ${ }^{1} \mathrm{H}-\mathrm{NMR}\left(400 \mathrm{MHz}, \mathrm{CDCl}_{3}, \mathrm{ppm}\right) \delta 1.25(\mathrm{t}, 6 \mathrm{H}, J=7.03 \mathrm{~Hz}), 4.07(\mathrm{~s}$, 4H), 4.18 (q, 4H,J=7.03Hz), $4.92(\mathrm{~s}, 2 \mathrm{H}), 6.47$ (d, 2H J=8.53Hz), 6.98 (d, 2H), 7.45$7.48(\mathrm{~m}, 4 \mathrm{H}), 8.03-8.05(\mathrm{~m}, 2 \mathrm{H}), 8.22-8.25(\mathrm{~m}, 2 \mathrm{H}), 8.43(\mathrm{~s}, 1 \mathrm{H}) ;{ }^{13} \mathrm{C}-\mathrm{NMR}(100 \mathrm{MHz}$, $\left.\mathrm{CDCl}_{3}, \mathrm{ppm}\right): \delta 13.72,32.02,53.06,60.53,112.26,124.40,124.54,125.26,125.82$, $128.45,128.57,130.04,130.12,131.24,132,03,145.68,170.50$; IR $\left(\mathrm{cm}^{-1}\right): 502.74$, $517.00,538.19,570.03,601.74,634.69,650.45,691.52,727.78,785.57,819.73,878.67$, $969.65,1065.24,1177.14,1273.96,1333.75$, 1354.81, 1385.98, 1447.14, 1479.87, $1520.96,1567.77,1614.95,1675.80,1764.87,1858.36,1931.18,1894.652976 .67 \mathrm{~m} / z$ 
(ESMS) $456\left(\mathrm{M}+\mathrm{H}^{+}\right)$. Anal. calcd for $\mathrm{C}_{29} \mathrm{H}_{29} \mathrm{NO}_{4}$ : C, 76.46; H, 6.42; N, 3.07. Found: $\mathrm{C}$, 76.18; H, 6.28; N, 3.07 .

\section{Synthesis of 7}

9,10-bischloromethylanthracene $(1.0 \mathrm{~g}, 3.63 \mathrm{mmol})$, phenyliminodi-acetic acid diethyl ester 2 (1.93 g.7.26 mmol) and $\mathrm{AlCl}_{3}(96 \mathrm{~g}, 7.26 \mathrm{mmol})$ were dissolved in dry $\mathrm{CHCl}_{3}(50$ $\mathrm{mL}$ ) at $0{ }^{\circ} \mathrm{C}$. The solution was refluxed under stirring overnight $(12 \mathrm{~h})$. After the reaction was complete, (monitored by TLC) the solution was cooled and washed with three 100 $\mathrm{ml}$ portions of water. The organic portion was dried over $\mathrm{MgSO}_{4}$. After evaporation of the solvent, crude product was subjected to column chromatography and yielded pure 7 $(1.56 \mathrm{~g}, 58 \%)$ as light yellow solid. ${ }^{1} \mathrm{H}-\mathrm{NMR}\left(400 \mathrm{MHz}, \mathrm{CDCl}_{3}, \mathrm{ppm}\right): \delta 1.27(\mathrm{t}, 12 \mathrm{H}$, $J=7.56 \mathrm{~Hz}$ ), 4.09 (s, 8H), 4.19 (q, 8H, $J=7.03 \mathrm{~Hz}$ ), 4.95 (s, 4H), 6.50 (d, 4H, $J=9.04 \mathrm{~Hz}$ ), 7.01 (d, $4 \mathrm{H}, J=9.04 \mathrm{~Hz}), 7.44$ (m, 4H), 8.27 (m, 4H); ${ }^{13} \mathrm{C}-\mathrm{NMR}\left(100 \mathrm{MHz}, \mathrm{CDCl}_{3}, \mathrm{ppm}\right)$ : $\delta$ 13.74, 32.30, 53.07, 60.54, 112.29, 124.79, 125.19, 128.49, 130.00, 130.25, 131.35, 145.68, 170.52; IR $\left(\mathrm{cm}^{-1}\right): 505.87,543.23,573.42,601.01,655.07,733.78,762.57$, $781.47,762.57,781.47,811.87,864.77,968.79,1029.90,1371.30,1447.59,1524.06$, 1568.16, 1615.59, 1733.87, 1858.36, 1931.18, 1894.94, 2978.96; m/z (ESMS) 733 $\left(\mathrm{M}+\mathrm{H}^{+}\right)$; Anal. calcd for $\mathrm{C}_{44} \mathrm{H}_{48} \mathrm{~N}_{2} \mathrm{O}_{8}: \mathrm{C}, 72.11 ; \mathrm{H}, 6.60 ; \mathrm{N}, 3.82$. Found: $\mathrm{C}, 72.26 ; \mathrm{H}$, $6.45 ; \mathrm{N}, 3.69$.

\section{Synthesis of 1}

$6(1 \mathrm{~g}, 2.19 \mathrm{mmol})$ was dissolved in Methanol $(20 \mathrm{~mL})$ under stirring .To this was added aqueous $\mathrm{KOH}(1 \mathrm{ml}, 3 \mathrm{M})$. The mixture was refluxed for 2 hours. After cooling to room temperature, the reaction mixture was kept in the fridge, when the potassium salt precipitated out. The resulting solution was filtered and precipitate dried in vacuum to afford 1 as pale yellow solid $(0.96 \mathrm{~g}, 92 \%){ }^{1} \mathrm{H}-\mathrm{NMR}\left(400 \mathrm{MHz}, \mathrm{D}_{2} \mathrm{O}, \mathrm{ppm}\right): \delta 3.67$ (s, $4 \mathrm{H}), 4.65$ (s, 2H), 6.20 (d, 2H, $J=8.5 \mathrm{~Hz}), 6.82(\mathrm{~d}, 2 \mathrm{H}, J=8.53 \mathrm{~Hz}$ ), 7.36-7.38 (m, 4H), 7.91 (d, $2 \mathrm{H}, J=5.5 \mathrm{~Hz}), 8.12$ (d, $2 \mathrm{H}, J=6.0 \mathrm{~Hz}), 8.30(\mathrm{~s}, 1 \mathrm{H}) ;{ }^{13} \mathrm{C}-\mathrm{NMR}\left(100 \mathrm{MHz}, \mathrm{D}_{2} \mathrm{O}\right.$, ppm): $\delta 29.22,53.54,109.48,122.57,123.20,123.95,124.06,126.55126 .68,126.89$, 127.61, 129.26, 131.10, 144.74, 177.61; IR $\left(\mathrm{cm}^{-1}\right): 518.99,535.06,563.69,601.29$, 617.76, 655.91, 696.59, 757.52, 790.25, 818.51, 851.76, 884.43, 902.58, 954.83, 986.62, $1100.35,1157.57,1185.53,1256.37,1335.66,1445.11,1500,1678.29,1722.60,1914.69$, 
1963.96, 2843.62, 2876.77; $\mathrm{m} / z$ (ESMS) $476\left(\mathrm{M}+\mathrm{H}^{+}\right)$; Anal. calc for $\mathrm{C}_{25} \mathrm{H}_{19} \mathrm{~K}_{2} \mathrm{NO}_{4} .2 \mathrm{H}_{2} \mathrm{O}$ :

C, 58.69; H, 4.53, N, 2.74. Found: 57.80; H, 4.33; N, 2.56.

\section{Synthesis of 2}

$7(1 \mathrm{~g}, 1.36 \mathrm{mmol})$ was dissolved in Methanol $(20 \mathrm{~mL})$ with stirring .To this was added aqueous $\mathrm{KOH}(2 \mathrm{~mL}, 3 \mathrm{M})$. The mixture was refluxed for 4 hours. After cooling to room temperature the mixture was kept in the fridge, when the potassium salt precipitated out. The resulting solution was filtered and precipitate dried in vacuum to afford $\mathbf{2}$ as pale yellow solid (0.95g, 90\%). ${ }^{1} \mathrm{H}-\mathrm{NMR}\left(400 \mathrm{MHz}, \mathrm{D}_{2} \mathrm{O}, \mathrm{ppm}\right): \delta 3.70(\mathrm{~s}, 8 \mathrm{H}), 4.86(\mathrm{~s}, 4 \mathrm{H})$, 6.28 (d, 4H, $J=6.12 \mathrm{~Hz}) 6.91$ (d, 4H, $J=6.12 \mathrm{~Hz}), 7.42-7.45$ (m, 4H), 8.29-8.31 (m, 4H); ${ }^{13} \mathrm{C}-\mathrm{NMR}\left(100 \mathrm{MHz}, \mathrm{D}_{2} \mathrm{O}, \mathrm{ppm}\right): \delta 31.13,45.30,55.11,111.11,124.95,125,23,128.15$, 128.41, 129.27, 146.34, 179.22; IR $\left(\mathrm{cm}^{-1}\right): 600.93,705.87,745.64,789.61,819.81$, 912.73, 975.86, 1028.83, 1043.12, 1208.81, 1319.92, 1403.78, 1445.83, 1515.06, 1573.68, 1659.60,1850.67, 2004.5, 3005.6; $\mathrm{m} / \mathrm{z}$ (ESMS) $773\left(\mathrm{M}+\mathrm{H}^{+}\right)$; Anal. Calcd for $\mathrm{C}_{36} \mathrm{H}_{28} \mathrm{~K}_{4} \mathrm{~N}_{2} \mathrm{O}_{8} .3 \mathrm{H}_{2} \mathrm{O}: \mathrm{C}, 52.28 ; \mathrm{H}, 4.14 ; \mathrm{N}, 3.39$. Found: C, 52.46; H, 4.02; N, 3.23 . 
${ }^{1} \mathrm{H} \&{ }^{13} \mathrm{C}-\mathrm{NMR}$ of Compound $1\left(\mathrm{D}_{2} \mathrm{O}\right)$
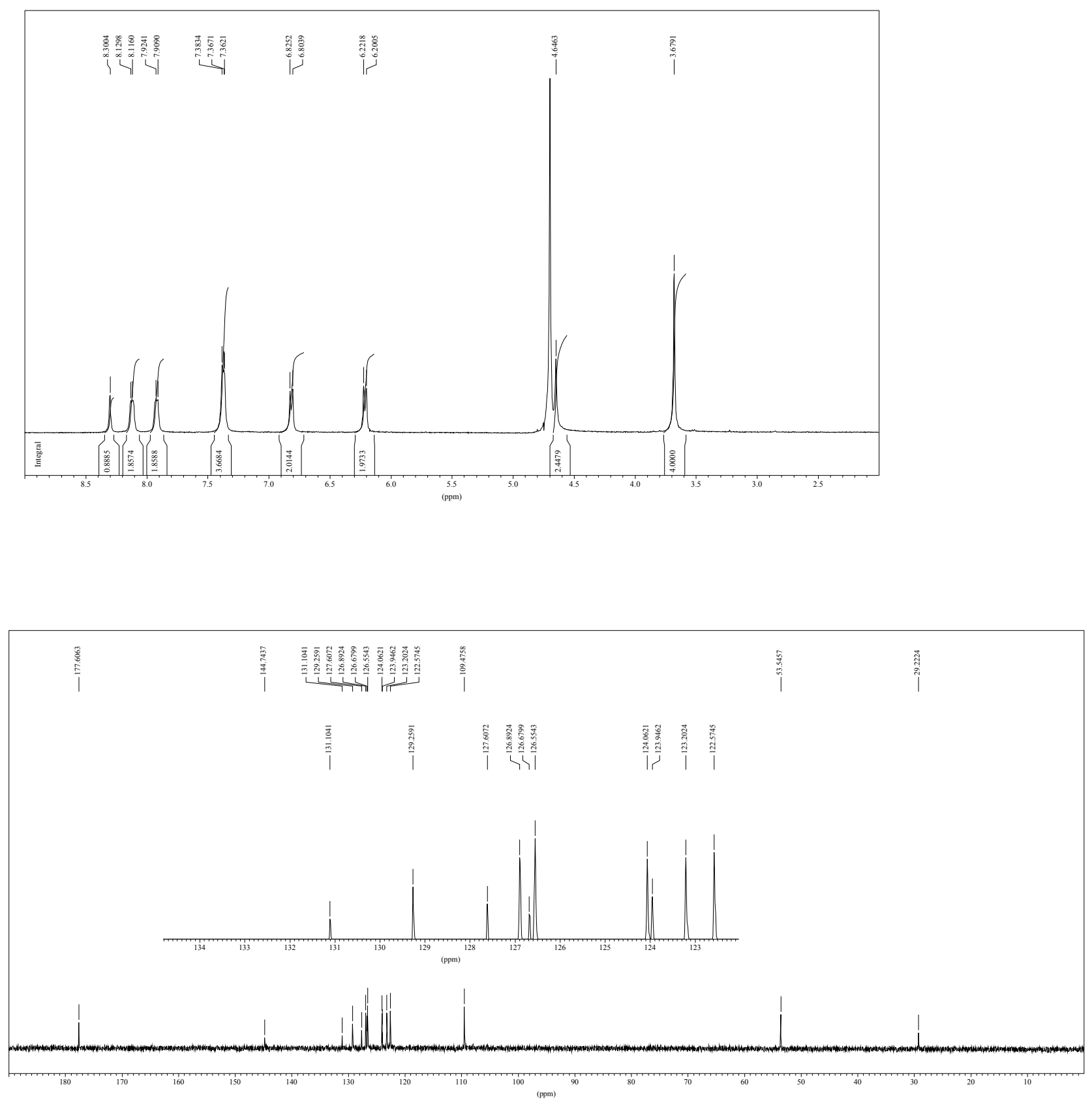
${ }^{1} \mathrm{H} \&{ }^{13} \mathrm{C}$-NMR of Compound $2\left(\mathrm{D}_{2} \mathrm{O}\right)$
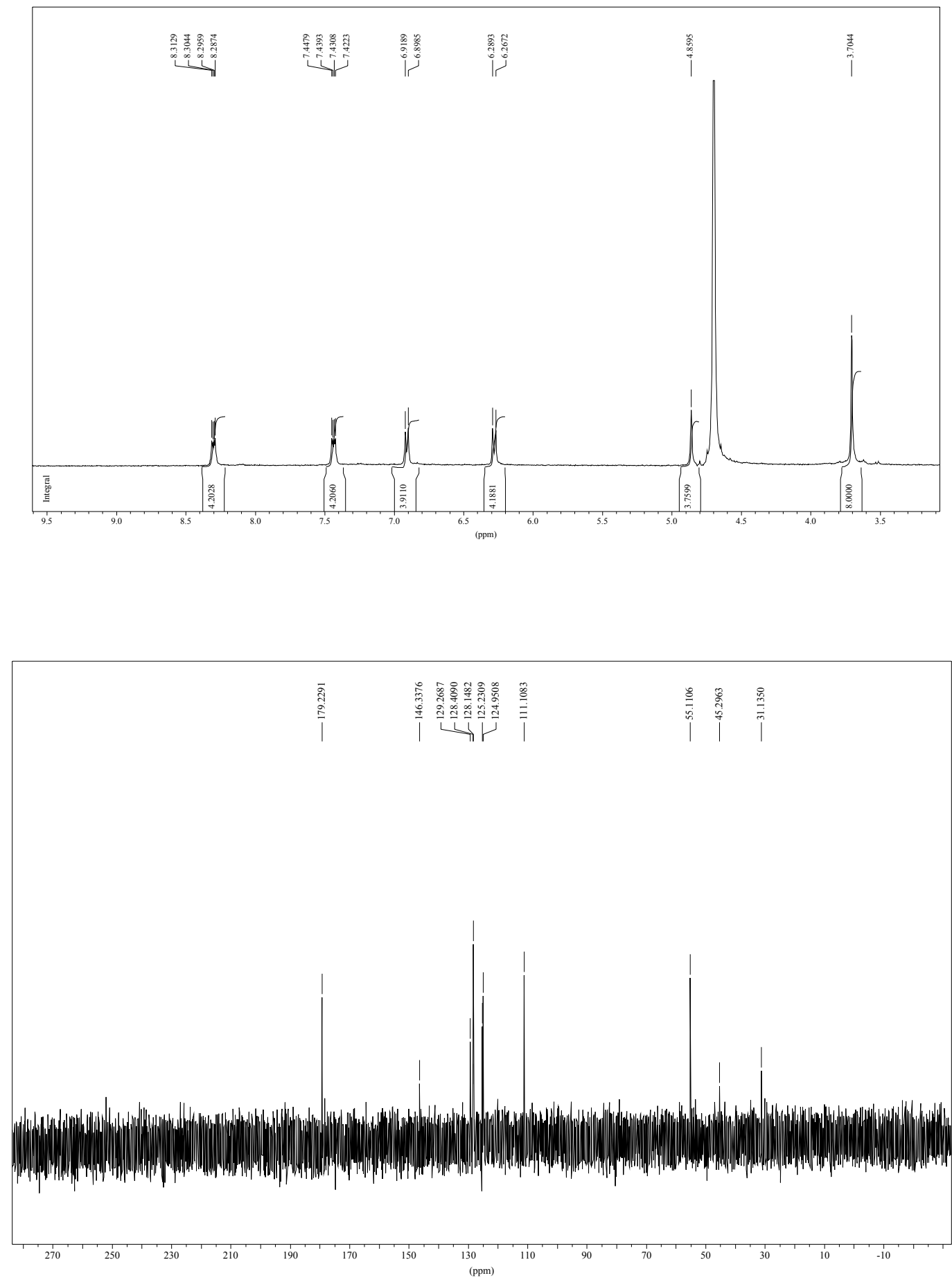
Changes in the fluorescence emission upon pH titrations of 2

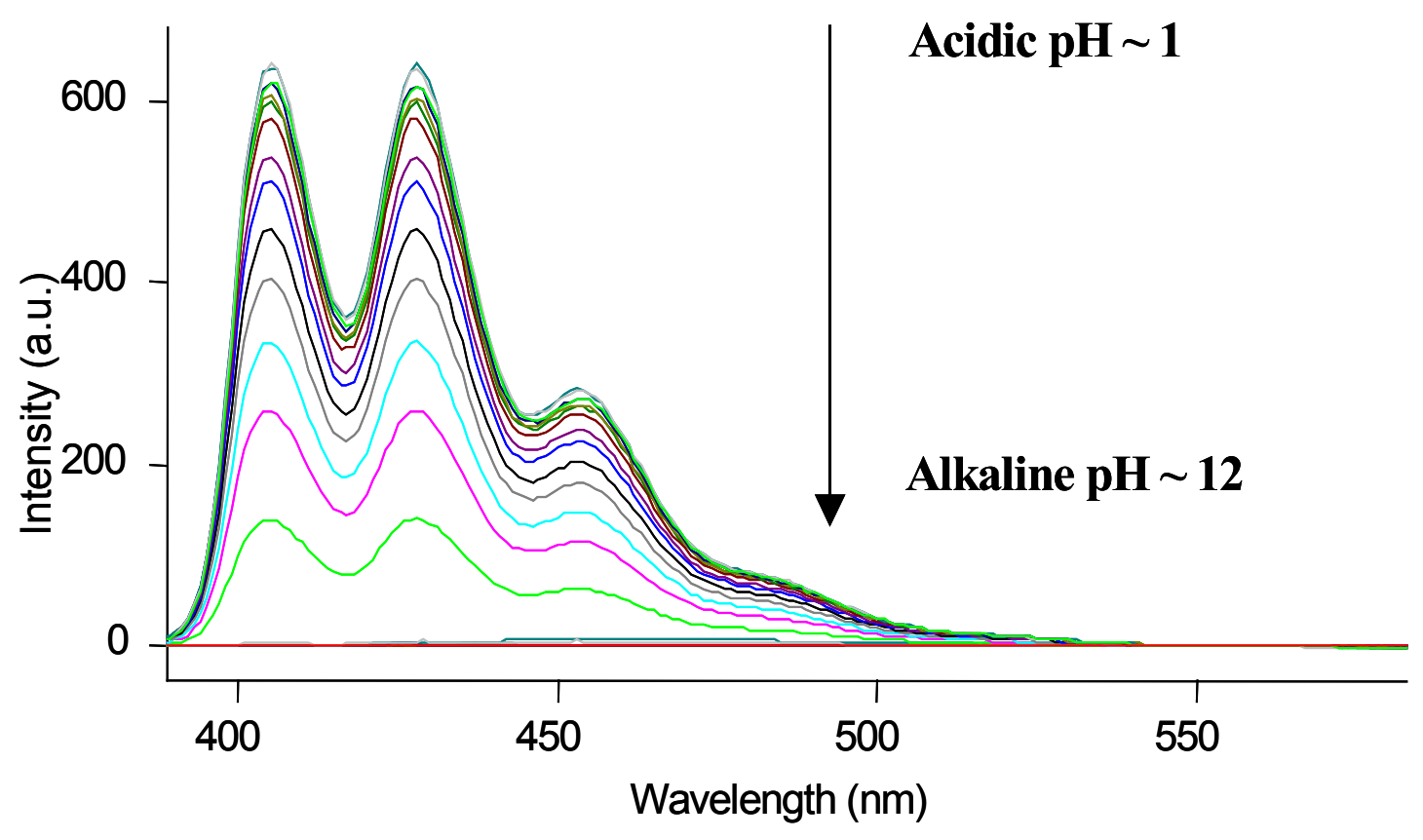


Fluorescence pH titrations of 1 (top) and 2 (bottom)
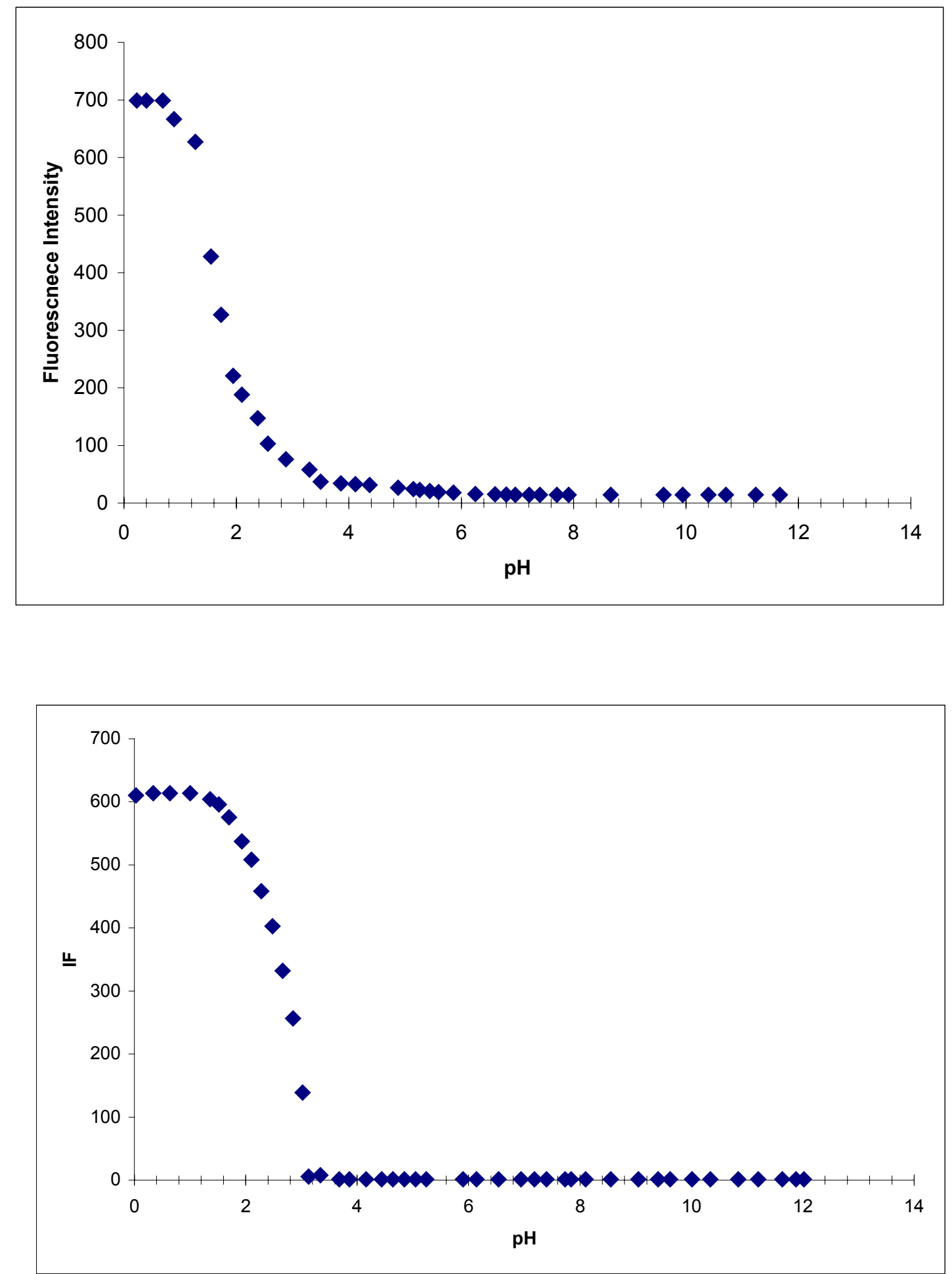
Changes in the fluorescence emission of 2 at pH 7.4 upon addition of $\mathrm{Cd}(\mathrm{II})$ to a solution of 2 in the presence of $\mathrm{Zn}$ (II).

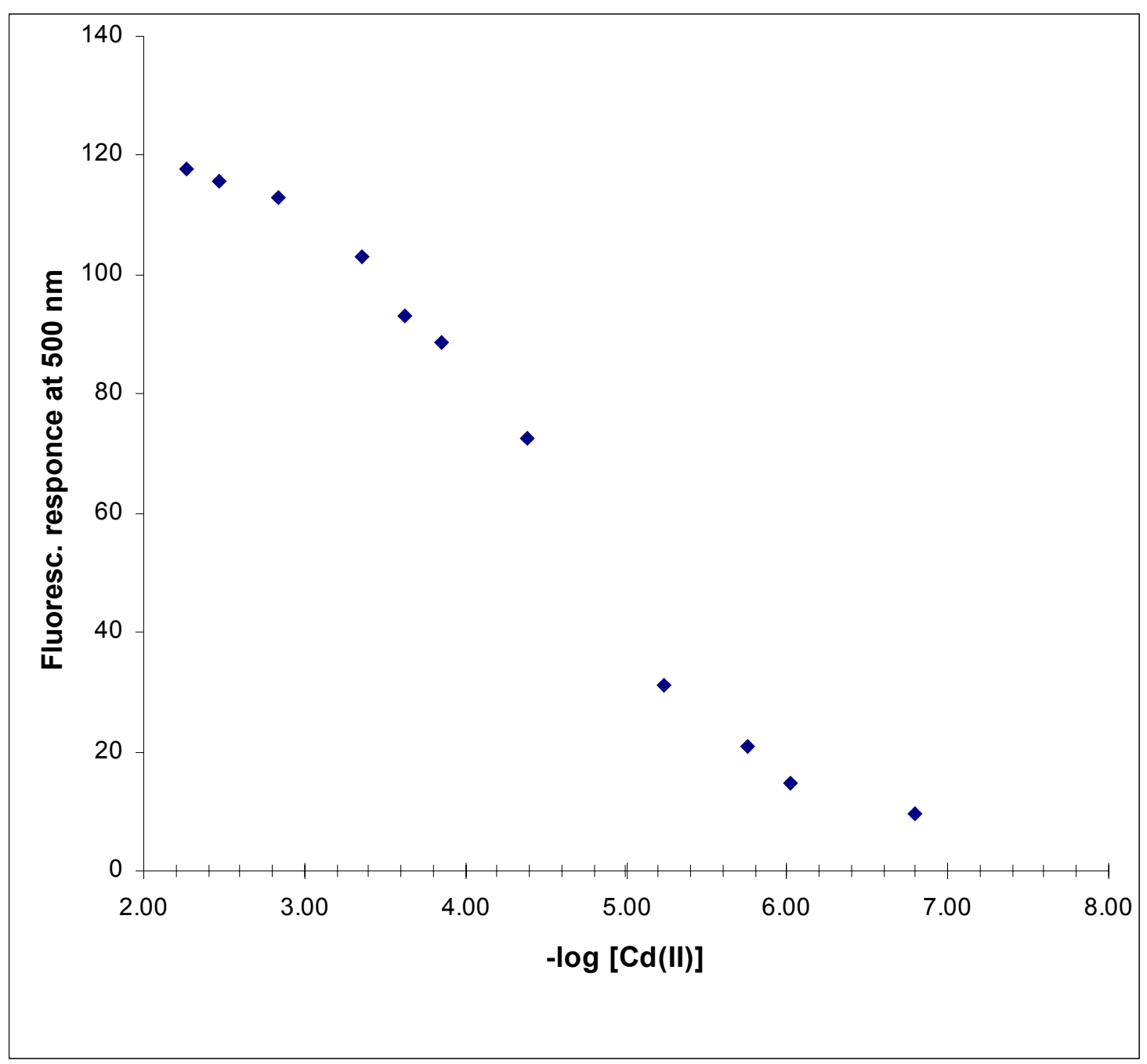


UV-Vis Titrations of 1 (top) and 2 with $\mathrm{Zn}$ (II)
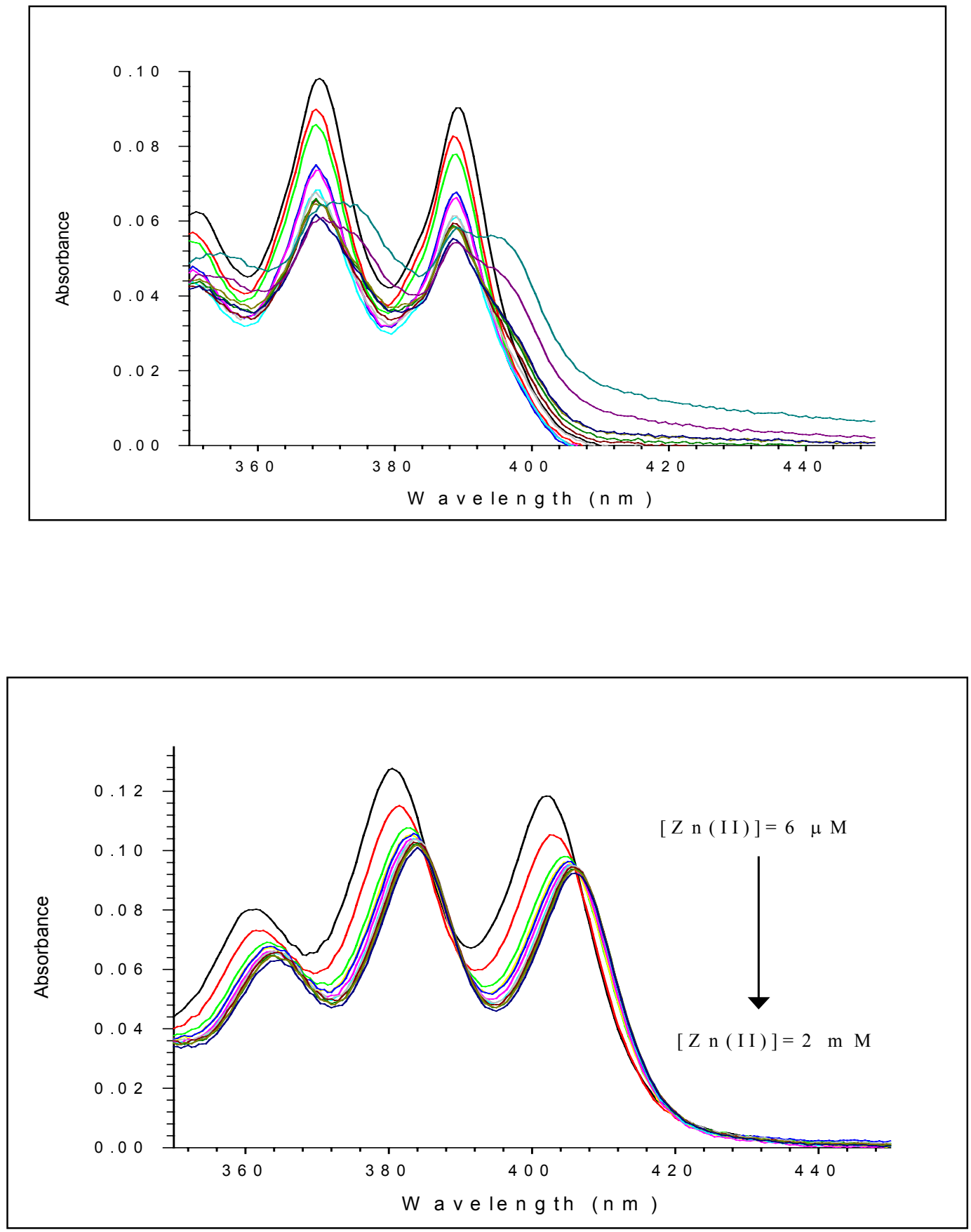
UV-Vis Titrations of 1 (top) and 2 with $\mathrm{Cd}(\mathrm{II})$
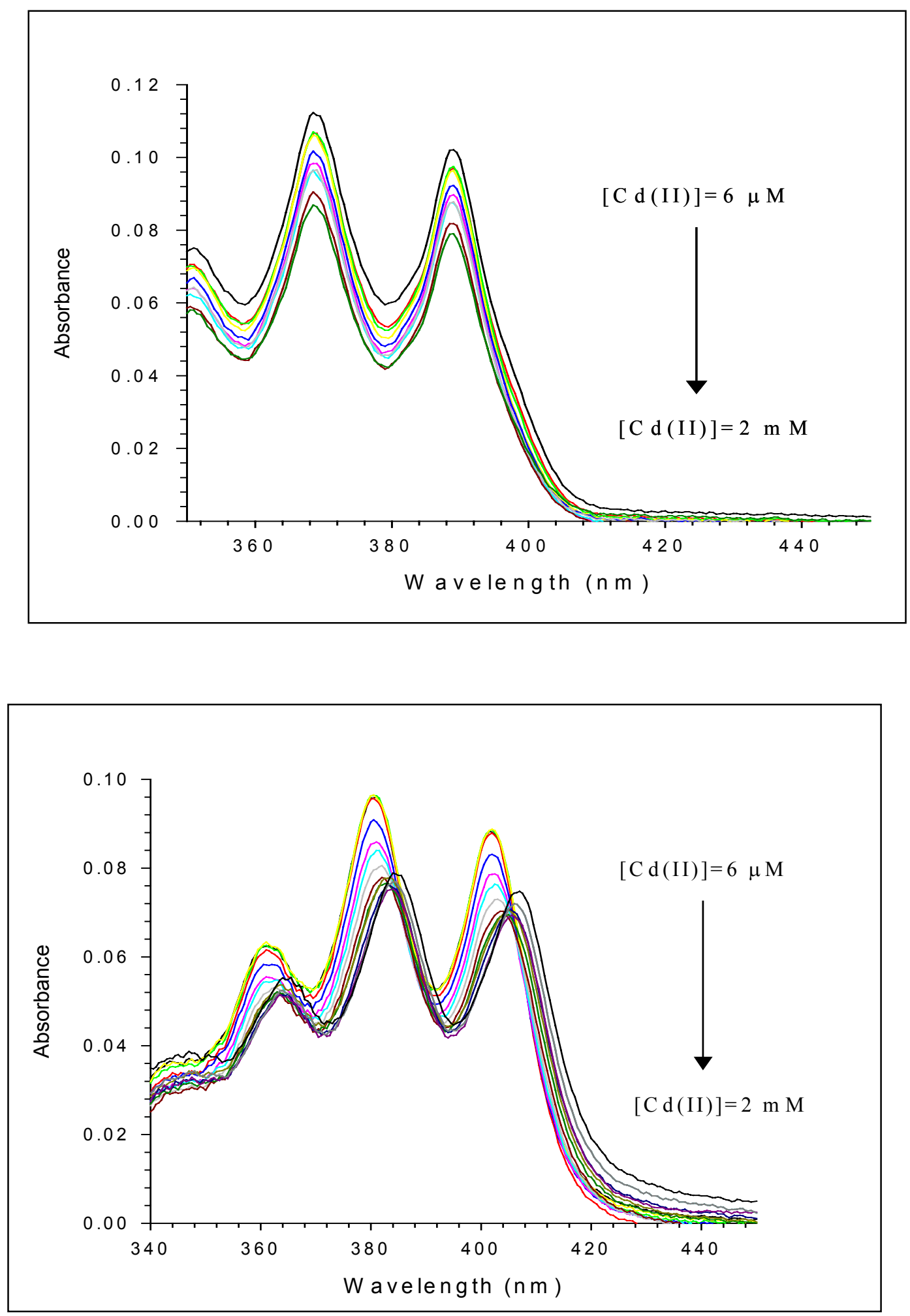